\title{
State-of-the-art of historical earthquake investigation in Bulgaria
}

\author{
Rumiana Glavcheva \\ Geophysical Institute of the Bulgarian Academy of Sciences, Sofia, Bulgaria
}

\begin{abstract}
This paper deals with non-instrumental seismology development in Bulgaria (the central-eastern part of the Balkan peninsula). The first steps and products of this scientific branch are discussed because they have traced the road of present-day historical seismology in this country. The sources of information on long-term seismicity are critically reviewed. Some recent studies, which contribute to an improvement of the supporting data sets, are also discussed. A special emphasis is laid on the rules adopted to solve different cases as well as on the aspects, by which our understanding of the seismogenesis throughout the present-day Bulgarian lands has been enhanced.
\end{abstract}

Key words macroseismology - bulletins and catalogues - supporting data set - site seismic histories - Bulgaria

\section{Introduction}

The beginning of Bulgarian seismology dates back to 1891. At that time Spas Watzof, the director of Central Meteorological Station in Sofia, organized a network of correspondents for observation of felt earthquakes. To unify the collected reports, Watzof prepared and spread circulated throughout country a special «Instruction and program on the earthquakes observation and documenting» (Watzof, 1902). All the reports coming to the Central Station were included in seismological compilations (Reports on the Earthquakes felt in Bulgaria). Thus, Watzof formed the proto-type of a macroseismic bulletin in Bulgaria which contained:

Mailing address: Dr. Rumiana Glavcheva, Geophysical Institute, Bulgarian Academy of Sciences, Acad. G. Boncev-st. bl. 3, 1113 Sofia, Bulgaria; e-mail: glavchev@geophys.bas.bg time of perceived shaking, locality, direction of impact, observed effects, intensity according to the volunteers' (correspondents') assessment by Rossi-Forel scale till 1912 or by Forel-Mercalli scale since then. The initial material on earthquakes felt in Bulgaria in the period 1892-1927 is published in this manner.

Going through the 17 annual volumes edited by Watzof (1902-1923), one can find that even at his time Watzof was concerned with some important topics, now considered quite common: «seismic centre» location (now, epicentre determination and source zones), density of observation points and territorial coverage (topics of great importance for both non-instrumental and instrumental data acquisition), accumulation of as many witness reports as possible from a given locality (statistical nature of modern intensity scales), etc.

The seismological survey employees coming after Watzof's death (1928) carried on with the macroseismic data collection. As a result of their efforts the scientific world received annual reports on earthquake effects in Bulgaria in the course of 74 years. So these annual reports were issued until 1965, though in different formats. 
The successor of Watzof was Kirov. The first issue edited by Kirov (1931) was, however, the last annual seismological compilation in Bulgaria which included eyewitnesses' descriptions. The presentation of data is organized by Kirov in the typical form of a classical macroseismic bulletin. Therein the main characteristics of the seismic impact are tabulated together with the effect strength uniformly assessed by a specialist. This style of macroseismic bulletin survived till 1966 when the last annual material on felt earthquakes was published.

In 1952 the first isoseismal maps appeared (Ileff, 1952). One can find macroseismic pictures of most of the Bulgarian XX century earthquakes with a $M 4$ or higher in the monographic work by Grigorova and Grigorov (1964) and in the atlases by Shebalin (1974) and Prohazkova and Karnik (1978). Isoseismal maps of some weaker or later events are published in a number of papers. Unfortunately, the intensity data points are not always shown in these maps and, though rarely, the intensity values assigned to individual localities had not been converted into the scale announced by the map's legend.

The main characteristics of the collections of records and products proceeding from this stage of the non-instrumental seismology in Bulgaria are summarized in table I. The non-instrumental seismology in this country covers the earlier times as well (Sections 2 and 3 be- low). The first steps in both the regular systematisation of the observations and searching for past earthquakes are the basis of historical seismology development in Bulgaria.

\section{First Bulgarian investigations on long-term seismicity}

At the very beginning of Bulgarian seismology two Bulgarians went back to the earthquake history, and their compilations have supplied information to the catalogues. That is why the reader is to be acquainted with the sources of these compilations and to understand how fully and how far critically they have been exploited.

Watzof was the first person in Bulgaria to pay attention to previous earthquakes. His findings refer to seismic events within the Balkans and are published in Supplements to the annual reports and in several papers (e.g., Watzof, 1908, 1912). These findings proceed from isolated records included in the works by 9th century Theophanes (De Boor, 1883) and by 11th cent. Symeon Magister and Logothete (Bekker, 1838), as well as from some widespread secondary sources like the ones by Schmidt (1879), Mushketov and Orlov (1893), etc. As to Bulgaria, three destructive earthquakes which occurred prior to the beginning of the 19th century are roughly outlined in the material supplied by Watzof.

Table I. Generalization on the sources of macroseismic information since the Bulgarian Seismological Survey started operating.

\begin{tabular}{|c|c|c|}
\hline Time span & Characteristic features & Sources of macroseismic information \\
\hline 1965-1980 & $\begin{array}{l}\text { The descriptive initial reports are partly transferred } \\
\text { into intensity-locality symbols }\end{array}$ & $\begin{array}{l}\text { Geophysical Institute's archive and } \\
\text { publications }\end{array}$ \\
\hline 1928-1965 & $\begin{array}{l}\text { Macroseismic bulletins for the entire time-span. The } \\
\text { archive of initial reports is complete since the late } \\
50 \text { s. }\end{array}$ & $\begin{array}{l}\text { Geophysical Institute's archive since } \\
1956 \text {; } \\
\text { Macroseismic bulletins published } \\
\text { (intensity-locality data plus some iso- } \\
\text { seismal maps). }\end{array}$ \\
\hline $1891-1927$ & $\begin{array}{l}\text { All the initial reports of the Bulgarian Seismological } \\
\text { Survey correspondents are preserved (compiled ac- } \\
\text { cordingto a special Instruction of how to observe and } \\
\text { what to note during earthquakes) }\end{array}$ & $\begin{array}{l}\text { Reports on earthquakes felt in Bulgar- } \\
\text { ia; published; } \\
\text { Isoseismal maps in papers published } \\
\text { later. }\end{array}$ \\
\hline
\end{tabular}


Watzof's most important contribution to past seismicity knowledge consists in gathering data from newspapers and journals in the National Library, Sofia. This data concerns Central Balkan earthquakes occurring during the second half of the 19th century (the first Bulgarian newspaper «Tzarigradski Vestnik» appeared on 3rd January 1848). Recently performed thorough investigation through the 19th century periodicals (Babachkova and Rizhikova, 1993) added not too many new pieces of information: a couple of weak (4 MSK) earthquakes in Kyustendil (SW Bulgaria); two local earthquakes in the vicinity of Tutrakan at the Danube river; some new information connected with the Sofia series in 1858-1859, and with the 1875 NE Bulgaria earthquake $\left(I_{\max }=7 \mathrm{MSK}\right)$; finally, several weaker events. Thus, the latter study verifies the good quality of Watzof's investigation through the periodicals.

Staiko Staikoff was the second to rummage for unknown earthquakes through ancient and recent literature, catalogues, periodicals, etc. His compilation (1930), based on findings in Central European libraries, covers 375 earthquakes or clusters occurring all over the Balkans and in Asia Minor, rarely in Italy, during the time period 3th century B.C.-1885. The earthquake records are ordered chronologically. A reference is attached to each entry, unfortunately not always supplying the source title or the year of publication. The extracted description is sometimes accompanied by the author's comment. It is rather probable that some of the sources cited by Staikoff have not been exploited directly but through the 19th century seismological compilations by von Hoff (1840), Mallet (1853), Schmidt (1879), etc., and some of them are known as second-hand sources (like most of Perrey's regional works, 1850). Despite being very laconic and presumably considering isolated localities, Staikoff's initial sources are not at a low level. When the outputs proceeding from Staikoff's findings and from the rather richer information in coeval sources, provided by Ambraseys and Finkel (1991, 1995) and Guidoboni et al. (1994) are juxtaposed, it turns out that the Bulgarian compilation results in nearly the same epicentral area and dates of the earthquake occurrence shifted by about 0-1 to $10-20$ years (Glavcheva, 1996). That is why the compilation by Staikoff (1930) still serves as a starting point towards the data set improvement for some Balkan and East Mediterranean earthquakes.

\section{Bulgarian earthquake catalogues with preference for macroseismic data}

The annual issues on seismic effects in Bulgaria and the seismological compilations considered above became the basis toward earthquake catalogues compilation. The first Bulgarian catalogue (Kirov et al., 1960) is of a mixed descriptive-parametric type, presenting the earthquake occurrence time, summarized description of maximum effects, epicentral or maximum intensity, epicentral geographical coordinates for earthquakes in Bulgaria or the geographical region of most likely epicentre location for foreign events, and the focal depth roughly assessed. It covers 344 events, which have caused effects of minimum 5 MSK (5 MCS then) in Bulgaria during the time-period 1892-1958.

The first parametric catalogue was compiled by Grigorova and Rizhikova (1966). It refers to the time interval 1961-1964. Therein, the instrumental magnitude based on records by the Wiechert seismograph appears. Later on, the joint Balkan earthquake catalogue (Shebalin et al., 1974), noted further by SHA74, was prepared, and was the first to deal with the longterm seismicity of Bulgaria. It covers most of the then known Bulgarian events (of a magnitude $M \geq 4$ ) since ancient times till 1970 . The primary material on this is extracted from the above considered Bulgarian compilations (part 2 ) and the annual macroseismic reports (part 1) according to Grigorova (1973). The last Bulgarian catalogue which also gives preference for macroseismic data lists medium-size and strong earthquakes in the 70ies (Sokerova et al., 1982). The study of any impressive present-day earthquake could be the reason for preparing a detailed historical earthquake catalogue of a certain portion of the country.

Aiming at updating the seismic zoning in Bulgaria, a revised catalogue was compiled at the end of the 1970s (Grigorova et al., 1978), noted 
further by GRA78. As a result of applying the principles and techniques already examined when creating the Balkan catalogue, the new catalogue presents more than 1400 entries within the territory enclosed in $40-46^{\circ} \mathrm{N}, 20-30^{\circ} \mathrm{E}$. About 930 of them correspond to earthquakes occurring in the present-day Bulgarian territory: $86.5 \%$ are supported by respective datasets and the rest come from other parametric catalogues. Two peculiarities of this catalogue should be noted: it does not fix the lowest earthquake size, and the intensity assessments are not unified. Later, Christoskov and Samardjieva (1980) published the main rules accepted for accuracy assessment in GRA78. It was postulated that the degree of cultural development was unambiguously related to the elapsed time. Proceeding from this, two ideas were suggested: 1) the earlier historical sources represent only quite strong or catastrophic earthquakes, and 2) going back in time the descriptions become more laconic, incomplete and less reliable.

And the maximum uncertainty of the parameters is established as: \pm 100 years in occurrence time, $\pm 200 \mathrm{~km}$ in epicentral coordinates, $\pm 2 \mathrm{de}$ grees in epicentral intensity for the old times. The first suggestion above can lead to a systematic overestimation of the earthquake size, especially when the information is poor. Concerning the second point, that the information reliability is directly connected with the period when the earthquake record was produced, this is rather simplified. It has been proved many times that the reporter's social responsibility, the reporter's attitude to natural events, the stress s/he puts on the political circumstances in the earthquake epoch, are crucial factors for reliability of the report.

Actually, the accuracy of earthquake parameters depends to a great extent on the quality of the data set from which the earthquake parameters are evaluated (the so called supporting dataset). The supporting dataset quality in Bulgaria has been improved in the course of time, although the intensity data points number has not been changed significantly. For instance, more than $50 \%$ of the earthquakes in Bulgaria which occurred before 1892 still are supported by a single locality report.

The next section is dedicated predominantly to various means of improving in the supporting datasets.

\section{Historical earthquake investigation in Bulgaria since the last 20th century decade}

At the beginning of the last decade of the 20th century, just a century after the pioneering efforts of Spas Watzof, a new search for earthquakes in the past was commenced through different kinds of compilations (historical sources, marginal notes, memoirs, inventories of Greek, Bulgarian, Slavonic and other manuscripts, etc.) thanks to serious support by the National Library, Sofia. This thorough work fulfilled by Babachkova and Rizhikova (1993) led mainly to first hand sources on unknown weak earthquakes in Bulgaria and to additional data on some strong earthquakes in the neighbourhood. At that time, I chanced to find a traveller's account (Galt, 1812) which pointed to an earthquake series realized near Plovdiv, South Bulgaria, in 18091811; the case was discussed together with other problematic seismic events in the XXIV ESC General Assembly (Glavcheva, 1994). Considering the importance of supplying a qualitative input information for solving the seismic hazard and risk connected topics, the historical seismology in Bulgaria focussed efforts on the following two tasks: 1) to examine again the circumstances related with some key catalogue events, starting from the original information; 2) to clarify the threat to some important sites often subjected to seismic impacts, i.e. to make the data on experienced effects as complete as possible. Figure 1 is an illustration of the cases developed below in connection with these two tasks.

\subsection{Flexibility of «the rules» supporting data set improvement}

The improvement of some datasets, connected with key-events, has become the goal of Bulgarian seismologists since the 1990s.

Case A - A transfrontier felt area: overcome disagreement by the very primary information.

Twelve solutions, independently found, belonged in the early Nineties to the 14 October 1892, Balkan earthquake. The epicentres were 


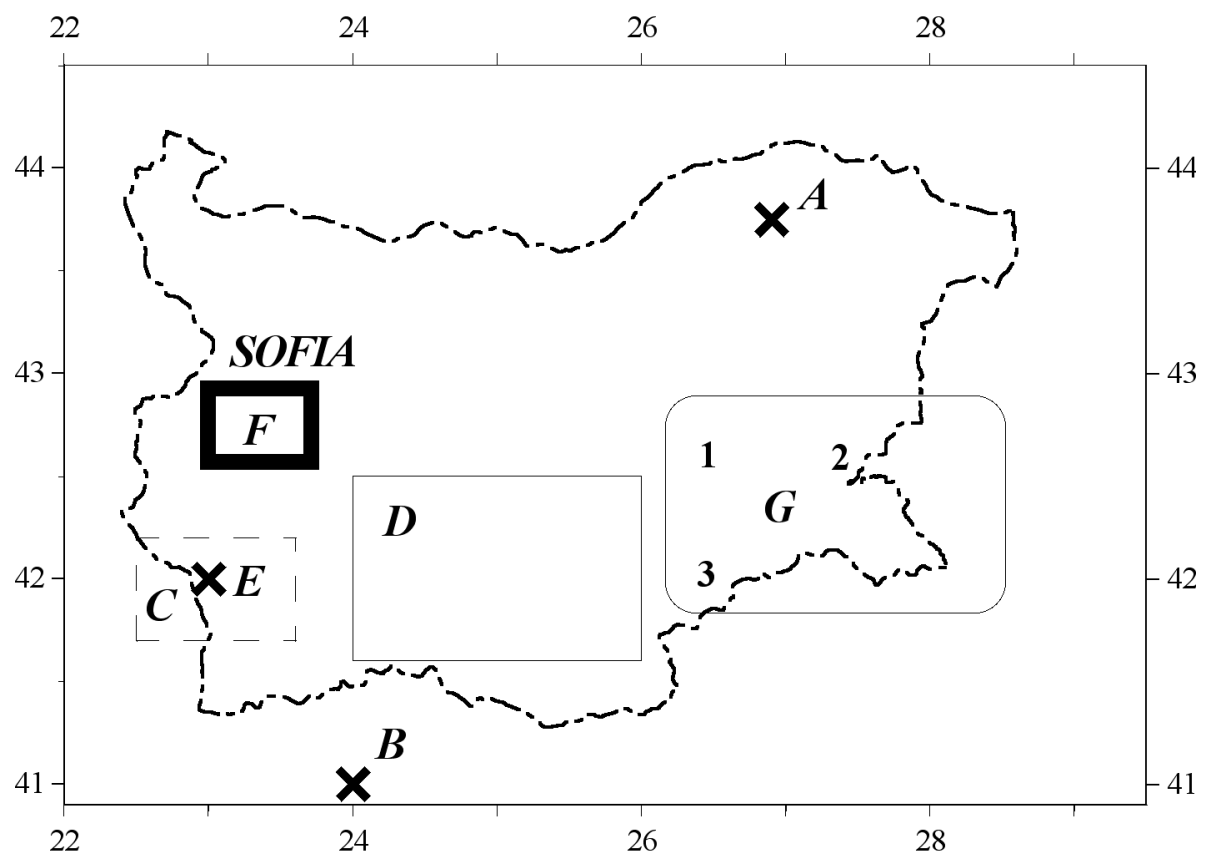

Fig. 1. Map of Bulgaria and cases of study. The rectangles denote the regions; the crosses mark the strong key events.

spread over more than $200 \mathrm{~km}$. Such a disagreement is shown to have been produced mainly by fragmentary use of the initial data (Glavcheva and Radu, 1994). The seismic intensities at 155 localities (previously being 95) are evaluated only on the basis of first-hand sources applying the same scale. After improving the supporting dataset in such a way, the so-called «Watzof's intensity assessments», actually intensity values assigned by the local reporters, have been avoided for the territory of Bulgaria. As the Romanian territory is concerned, the second hand sources have been omitted at solving this case. The earthquake main parameters have been derived, as accurately as possible, from the intensity distribution: seismic source location in South Dobrodja at a depth of a minimum $35 \mathrm{~km}$, epicentral intensity $8 \mathrm{MSK}$, the corresponding magnitude up to 7 .

Case $B$ - The catalogue solution provides matters of uncertainty due to the careless reading of a record.
The following account exists in the Balkan Earthquake Catalogue SHA74: «1759, June 26 or 29, the towns Thessaloniki and Plovdiv suffered great damage, epicenter in the Pirin mountains or in Struma valley (9?; 41N, 24E); $403 / 4 N, 23 E, 8$; two shocks?, according to Staikoff (1930), Montandon (1953), Galanopoulos (1961)». Thus, the catalogue provides a matter of uncertainty.

The case needs contemporary reports. And the report has been found. The Collection Academique (Guéneau de Montbéliard, 1761), among its descriptions on an earthquake sequence near Thessaloniki, wrote: «La Ville de Phillipolis dans le voisinage de Salonique, a beaucoup souffert de ce meme tremblement.» So it became clear that the original Phillipolis had been replaced by Philippopolis (Plovdiv) in the classical compilations by von Hoff (1840), Perrey (1850), Mallet (1853). The erroneous reading was inherited by Milne (1911), Montandon (1953) and finally was entered in the 
Balkan Catalog SHA74. After analyzing the information from the earthquake time, the following conclusions are drawn by Glavcheva (2000a).

i) An earthquake series occurred during June-September 1759 in the Thessaloniki surroundings. The activated space was most likely somewhere in the narrowest part (the «neck») of the Halkidiki Peninsula, where the great 1902 activation would take place. The strongest earthquake (or two earthquakes) of the series might have a magnitude ranging between 6.6 and 7 .

ii) In the area of Phillipoe a strong local shock occurred simultaneously with the Thessaloniki series.

iii) The Bulgarian town of Plovdiv was involved in the 1759 earthquake sequence due to a careless reading of the initial record. Thus, the suspicious 1759, «9 [MSK]?, 41N, 24E» event in the border Greece-Bulgaria region must be dropped from the earthquake catalogues.
Case $C$ - An «energy» catalogue evidences seismic precursory features.

An impressive seismic activity developed in the transfrontier region of SW Bulgaria-Macedonia during 1904-1906. The seismic sequence started on 4 April 1904 with two catastrophic earthquakes within $23 \mathrm{~min}$ (MLH = 7.1 and 7.8 in SHA74, $M_{s}=6.9,7.2$ by Ambraseys (2001). Recently Glavcheva (2000b) compiled an «energy» catalogue of the sequence; an excerpt for the first 100 minutes is plotted in fig. 2b. For this purpose two problems had to be solved when processing the initial data (Watzof, 1902-1923): interruption of data flow coming from the damaged area (epicentral distance up to about $50-80 \mathrm{~km}$ ) and accumulation of damage. To overcome difficulties, reports from localities at epicentral distance more than $50 \mathrm{~km}$, outside the area most damaged by the first severe earthquake, are mainly taken into account. To distinguish separate events, the «relative time differences» $\left[t_{M}(i)-t_{A}(i)\right]$ are used, as shown

Table II. Problems and ways of achieving results in cases C and D.

\begin{tabular}{|c|c|c|c|}
\hline Case & Roots & $\begin{array}{l}\text { Intensity data set creation } \\
\text { - influence taken into ac- } \\
\text { count }\end{array}$ & Dataset processing \\
\hline $\mathrm{C}$ & Watzof (1905-1907) & $\begin{array}{l}\text { - interruption of recordings } \\
\text { from the epicentral area; } \\
\text { - damage cumulation }\end{array}$ & $\begin{array}{l}\text { Occurrence time determination } \\
t_{A}(\text { abs })=t_{M}(\text { abs })-\left[t_{M}(i)-t_{A}(i)\right]\left(^{*}\right) \\
\text { Magnitude evaluation } \\
(\text { Glavcheva, } 1997) \\
M=2.36 \log R_{3}\left(^{* *}\right) \\
r=0.90(45 \text { events; } M \text { up to } 7.2) \text {; } \\
M=2.45 \log R_{4}+0.49 \\
r=0.92(55 \text { events; } M \text { up to } 7.8) \text {. }\end{array}$ \\
\hline $\mathrm{D}$ & $\begin{array}{l}\text { Watzof (1902-1923); } \\
\text { Kirov (1931); } \\
\text { Mihailovic (1932); } \\
\text { local press }\end{array}$ & $\begin{array}{l}\text { - observation network } \\
\text { geometry; } \\
\text { - observational points speci- } \\
\text { ficity; } \\
\text { - conditions at the moment } \\
\text { of recording }\end{array}$ & $\begin{array}{l}\text { Interpreted four sorts of quality } \\
\text { of the macroseismic field }\end{array}$ \\
\hline
\end{tabular}

(*) $t_{M}(i)$ and $t_{A}(i)$ are times of the main shock and of a concrete aftershock reported from the same locality «i»; $t_{M}(\mathrm{abs})$ is the actual time of the main earthquake; $t_{A}(\mathrm{abs})$ is the true time of a given event $A ;\left[t_{M}(i)-t_{A}(i)\right]$ is the «relative time difference».

$\left(^{* *}\right) R_{3}$ and $R_{4}$ are the mean isoseismal radii of 3 and 4 MSK respectively. 
(a)

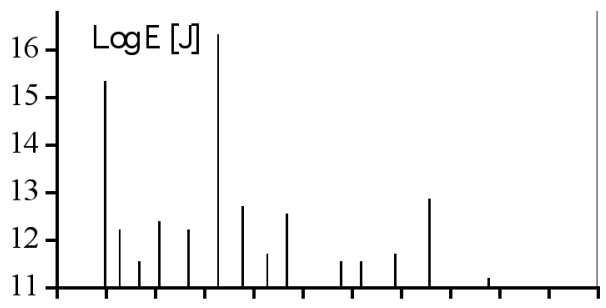

(b)

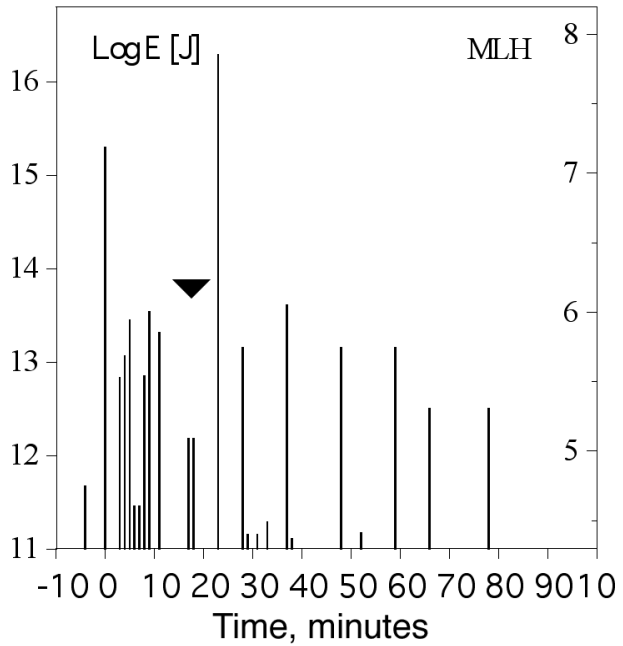

Fig. 2a,b. Energy release at the start of the 1904 seismic activation in Bulgaria - Macedonia (Case C): according to the last Bulgarian earthquake catalogue (a) and after the initial records reassessment at fixed regulations (b). Note the significant decrease in the mean energy released per single event before the second catastrophic earthquake (the arrow).

in table II. The earthquake magnitudes have been assessed by the distant felt area sizes, applying intensity attenuation relations from SHA74. The list of events has been controlled by the continuous earthquake recording supplied by two meteorological stations in Rila Monastery and Borovetz. These uninterrupted records guarantee completeness of the seismic events listing, i.e. of the «energy» catalogue, at a lower threshold $M 4.5$.

According to this catalogue, the seismic source maximal activity turns out to have been in the interval between the two largest earthquakes. This very period, unfortunately the most slightly known one until late 1990's, presents the most curious stage of the rupture process. Indeed, the national catalogue GRA78 shows that the energy release pattern is quite monotonous (fig. 2a), while the sample derived from the new catalogue discloses precursory time variations of the energy release mode, more precisely - a seismic activity decrease starting in the middle of the interval between the two largest shocks (fig. 2b).

Case D - An overall picture of a catalogue revision.

The Maritza seismic zone in Central South Bulgaria is well known with the 1928 catastrophic earthquakes ( $M 6.8$ and 7.0 according to the catalogue SHA74) because they caused two surface coseismic ruptures, each of them several tens of kilometers in length, and much loss as well. The current dense population and industry concentration require better knowledge of the former seismogenesis in the zone. A thorough review of 


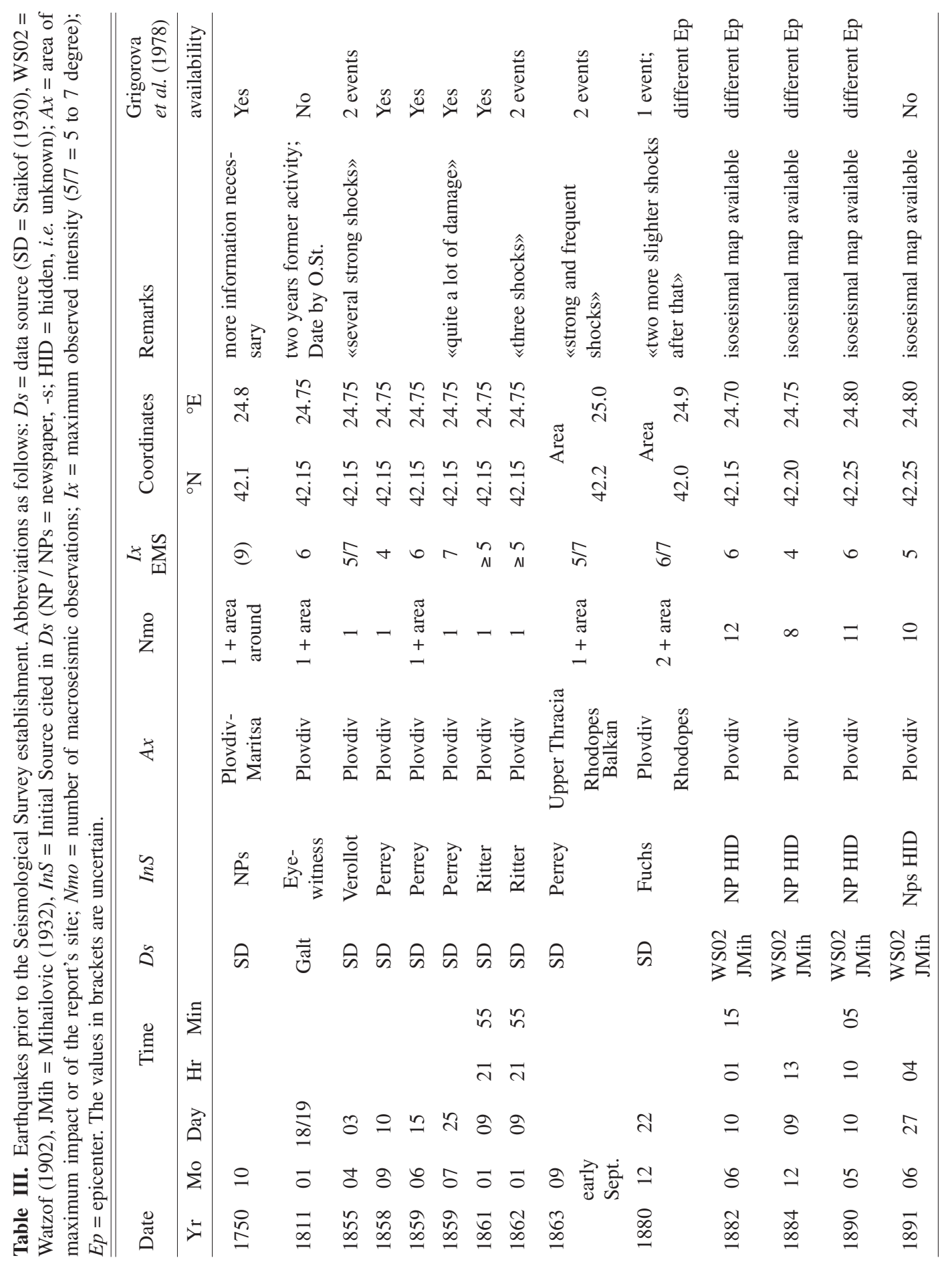


the supporting datasets for the earthquakes prior to 1928 has been carried out. Different sorts of primary records corresponding to the earthquake «epoch» are involved in processing these events.

For the time prior to the Bulgarian Seismological Survey, the supporting datasets are predominantly extracted from the works by Staikoff and Watzof presented above. They correspond mostly to contemporary earthquake reports. The resulting revised catalogue (table III; fig. 3, plot II) has the following advantages compared to the latest Bulgarian catalogue (fig. 3, plot I). It 1) leads to two more main events (14 in total); 2) shows the site intensity and geographic coordinates of the report's locality without fabricating any epicentre (the first 9 cases in the table), in a case of initial data deficiency; 3 ) indicates the availability of accompanying shocks; 4) contains some entries being specified after adding a new source.

For the time following till the severe earthquakes in April 1928, primary documentation of a good quality (Watzof, 1902-1923; Kirov, 1931) has come to us. It has been used as a basic source for the catalogues up to now (fig. 3, plot III). Recently, new pieces of information were found (table II) and the catalogue revision became necessary (Glavcheva et al., 2000). When compiling the supporting intensity data set, three important factors have been considered: the influence of the observation network geometry, the observational point's specificity (systematic or occasional reporting, complete or partial descriptions of effects, detailed or laconic records), and the specific recording conditions (day-time, season population activity, saturation of people's sensitivity).

Finally, depending on the macroseismic field quality, four groups of cases have been solved: 1) many intensity data points (IDP) and areas with different degrees of effects; 2) many points of the same intensity in the distant part of the macroseismic field and known felt area size; 3 ) few IDP with a different intensity degree (this case is reduced to case 1 , the solution being of lower accuracy); 4) few IDP with the same intensity degree and surrounding settlements without any other information except being a regular contrib-

Prior to 1892
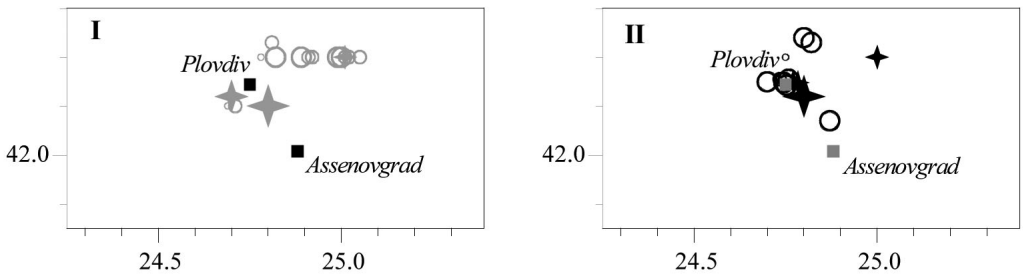

Intensity MSK

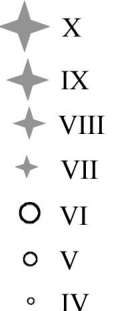

1892 - 1928, March
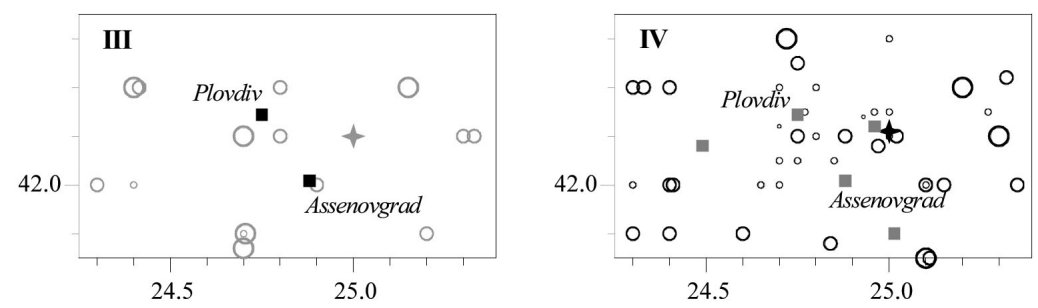

- observation point

Fig. 3. Past seismicity of Central South Bulgaria (Case D): prior to the Seismological Survey establishment according to the catalogue GRA78 (plot I) and this study interpretation (plot II, see also table III); since 1892 until the 1928 catastrophic earthquakes according to GRA78 (plot III) and results from (Glavcheva et al., 2000) (plot IV), the latter plot evidences a good coverage of the region by observation sites. 
utor of data on felt earthquakes; the territorial distribution of such settlements favours the macroseismic area outlining (analogous with case 2; lower accuracy). The manner of the earthquake main parameters determination is that applied in the Balkan catalogue SHA74. The new catalogue includes $46 \%$ more events than the latest Bulgarian catalogue GRA78 (fig. 3, plot IV). Additionally, a settlement - intensity (MSK) database has been developed for each event and the intensity data points plotted on a map.

Case E-False warnings in the latest Bulgarian catalogue.

This case shows how the unreasonable combination of two pieces of information: $« 6$ December 1866: strong shock in Thessaloniki» (Fuchs,1886; Staikoff, 1930) and «A heavy shock damaged some old houses and poor walls at Sofia» (Watzof, 1902) has led to the fabrication of the destructive 1866 earthquake in SW Bulgaria listed in three catalogues: of the Balkan Region, Bulgaria and Greece. The steps of data processing for this false event were: setting the epicenter in the mid-point between the two reported localities; solving an elementary puzzle by the corresponding intensity attenuation relation and, in result, surprisingly high epicentral intensity -8 or more MSK (!?). The catalogue entries preceded are: «December? A heavy shock damaged some old houses and poor walls at Sofia (Watzof, 1902); Grigorova gives $I=$ VIII for the region of the Struma valley; incomplete information» in Karnik (1971); «6 December 1866 ? old houses and walls damaged in Sofia, epicentre in the Struma valley $\left(8^{\circ}\right.$ ?), strong in Thessaloniki, according to Fuchs, 1886; Karnik, 1971; Grigorova, 1973» in Shebalin et al. (1974); «18 December 1866 [?], 16h 25min UT, $42.0 \mathrm{~N}, 23.0 \mathrm{E}, H=40, \mathrm{Mms}=7.1 »$ in Grigorova et al. (1978); «6 December 1866 16:25 42.0 23.0 $H=$ normal $M=7.0$ Bulgaria $\left(\right.$ Sofia $7^{\circ}$ )» in Comninakis and Papazachos (1982).

The following facts argue against assigning the 6 December 1866. earthquake to the middle Struma valley: 1) Such an earthquake has not been mentioned by authoritative catalogues as these by Schmidt (1879), Milne (1911), Sieberg (1932), Montandon (1953) or Galanopoulos (1960); 2) No record from Skopje, TatarPazardjik, Plovdiv - important transport and trade centres then, which should have been concerned by a magnitude 7 earthquake in SW Bulgaria - can be found; 3) The most significant arguments may be found in the primary documentation of later strong earthquakes that occurred in the same region.

The well developed interpretation of the data concerning four later earthquakes in the middle Struma valley has been summarised in table IV. Twelve localities situated at a distance of no more than $100 \mathrm{~km}$ from the above supposed 1866 epicentre are shown in the table (columns 1 and 4). After considering the intensity attenuation according to relations published in SHA74, it turns out that in each of the considered localities (Dupnitsa is the only exception), the 1866 earthquake should have caused intensity (column 5) of one to two degrees higher than the maximum intensity experienced during the four later earthquakes (column 3). However, the quoted phrases (column 2) extracted from the reports on the later earthquakes in 1894, 1903 and 1904 (Watzof, 1902, 1904, 1905) completely reject the possibility of a stronger former event. Unfortunately, the town of Dupnitsa remains the exception according to the results of the comparative analysis here.

Several records of shocks occurring around the end of 1866, along and near the Struma River, exist in the 19th century documentation. One of them is the excerpt of the Fuchs's catalogue (Staikoff, 1930), according to which the occurrence of an earthquake in Thessaloniki on 6 December 1866 is irrefutable. Watzof's volume on the 19th century earthquakes in Bulgaria (Watzof, 1902) also supplies data (newspaper «Vremya», issues $14,16,17,21$ ) thanks to which we learn two essential things. First, several not very impressive shocks had occurred: 14 November 1866, [N.St.], a slight shock in Samokov, about 4 MSK; 26 November 1866, an earthquake in Sofia which had caused some damage, 6 MSK most likely, the same shock was also felt in Dupnitsa, 4 to 5 MSK; 1867, first half of January, Sofia, 5 to 6 MSK. Second, the only questionable entry in table IV, Dupnitsa, is proven not to have experienced even 7 MSK. Thus, the available 19th century documentation gives strong evidence that no severe shock occurred in the middle Struma valley in the late 1866. 
Table IV. Data for checking the authenticity of an earthquake in 1866 in the middle Struma valley. The reports from the national seismological network (Watzof, 1902, 1904, 1905) have been used.

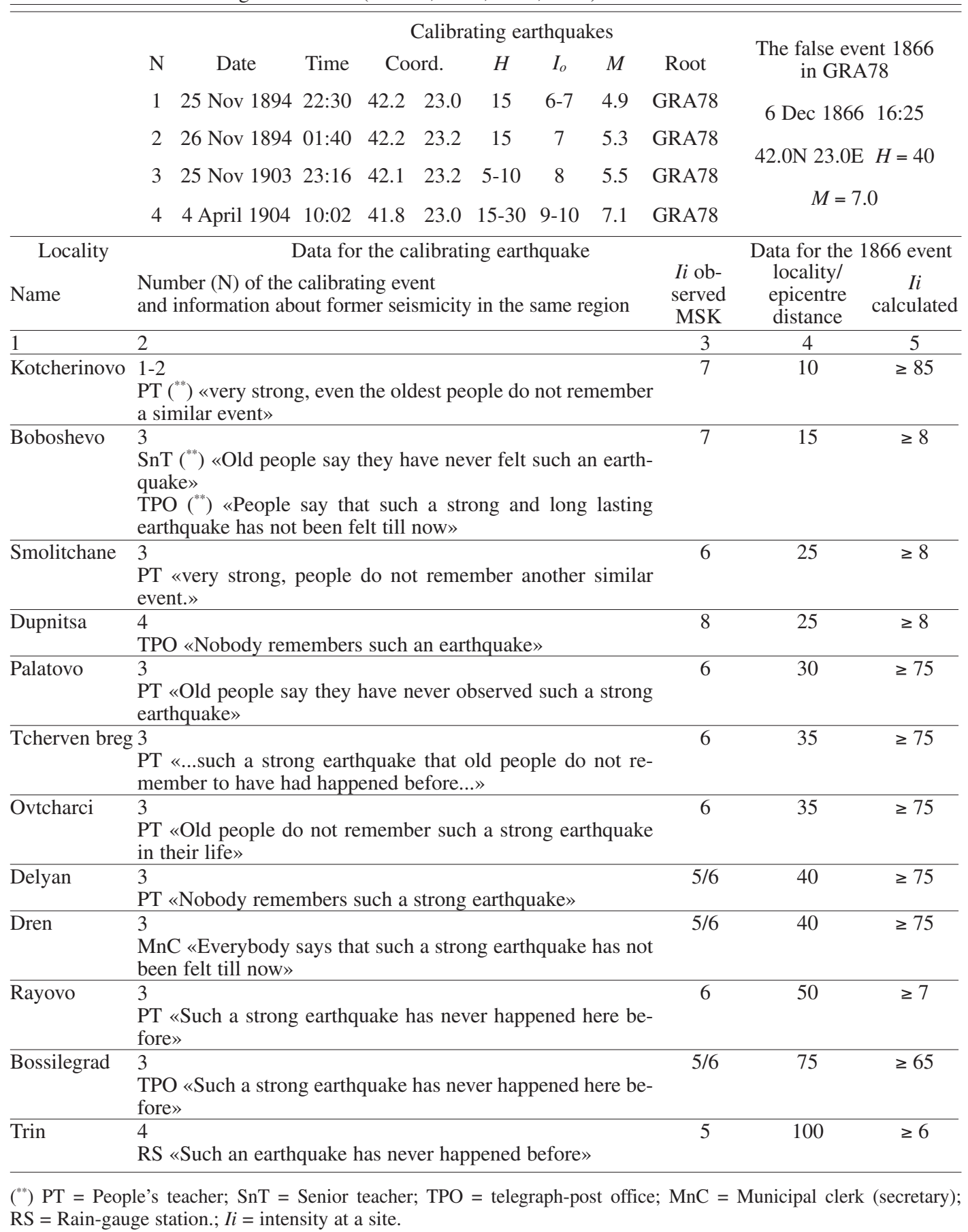




\subsection{On the site seismic history}

The time seismic histories of two regions, Sofia and SE Bulgaria, have been studied in order to widen the acquaintance with the longterm seismic influence on them. This has been done in the following succession: i) retrieval of all eyewitnesses earthquake records, or scientific summaries on them, i.e. compiling of the maximum complete set of initial data for seismic effects on concrete places; ii) intensity reassessment of the effects; iii) identifying the causal seismic events; iv) calculating the site intensity in case of description deficiency after normalizing the intensity-distance attenuation to some well compiled macroseismic pictures.
The two regions are separately considered because of their specific problems.

Case F - Sofia seismic history.

Prior to the 19th century Sofia was a small town, deeply inside the Ottoman Empire, and only few reports on earthquakes felt therein could be mentioned. For this reason, the strength of excitation on Sofia has mainly been determined by analogy with some recent well solved events. Later, most of the seismic effects are documented and the intensity is possible to assess. Thus, in the period since the early 19th century to date, seismic influences on Sofia which have been identified (fig. 4a-c), are: a) from nearly a hundred local earthquakes, without taking into account the long-lasted sequences in 1818 and 1858 , and b) twice more than the previously
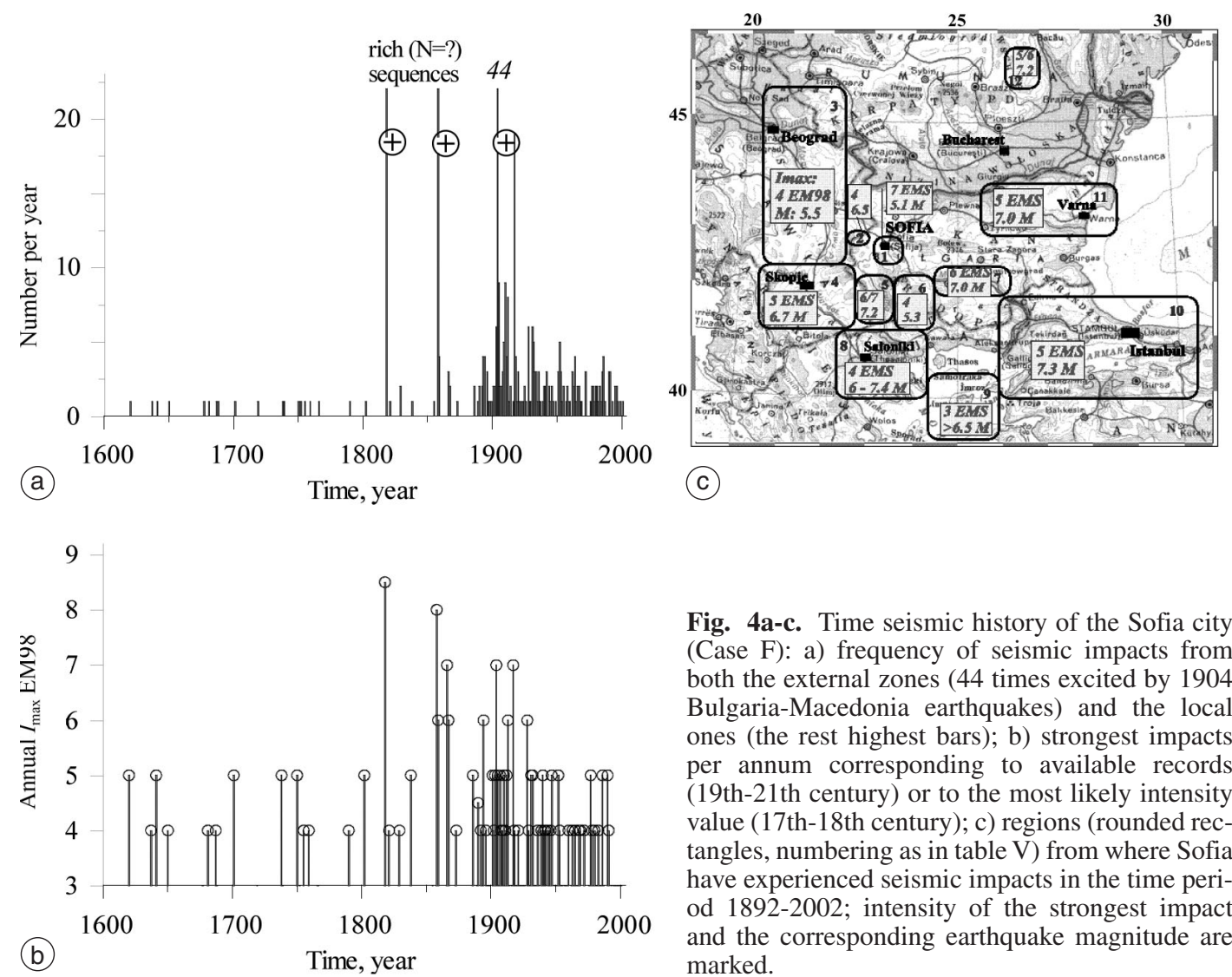

Fig. 4a-c. Time seismic history of the Sofia city (Case F): a) frequency of seismic impacts from both the external zones (44 times excited by 1904 Bulgaria-Macedonia earthquakes) and the local ones (the rest highest bars); b) strongest impacts per annum corresponding to available records (19th-21th century) or to the most likely intensity value (17th-18th century); c) regions (rounded rectangles, numbering as in table V) from where Sofia have experienced seismic impacts in the time period 1892-2002; intensity of the strongest impact and the corresponding earthquake magnitude are marked. 
Table V. Distribution of damaging seismic effects $\left(I_{\min }=5\right.$ EMS $)$ on Sofia during the period of regular seismological observations in Bulgaria, 1892-2002. The seismogenic regions are shown in fig. 4a-c, plot C (here: numbering in brackets).

\begin{tabular}{lllll}
\hline \hline $\begin{array}{l}\text { Seismic impact } \\
\text { source region }\end{array}$ & $\begin{array}{l}\text { Relative amount } \\
\text { of effects, } \%\end{array}$ & $\begin{array}{l}\text { Maximum } \\
\text { intensity in Sofia }\end{array}$ & $\begin{array}{l}\text { Magnitude caused } \\
I_{\max }\left[\text { study }\left(^{*}\right)\right]\end{array}$ & $\begin{array}{l}\text { Event causing } \\
\text { maximum effect }\end{array}$ \\
\hline $\begin{array}{l}\text { Area of } R \leq 30 \mathrm{~km} \\
\text { centred at Sofia (1) }\end{array}$ & 40.0 & 7 & 5.1 [GRA78] & 18 October 1917 \\
$\begin{array}{l}\text { Struma valley and Rila } \\
\text { Mt. (5) }\end{array}$ & 32.5 & $6 / 7$ & 7.2 [AMB01] & 4 April 1904 \\
Maritsa valley (7) & 4.0 & 6 & 7.0 [GRA78] & 18 April 1928 \\
Vrancea (12) & 4.5 & $5 / 6$ & 7.2 [COR79] & 4 March 1977 \\
Macedonia (4) & 5.0 & 5 & 6.7 [SHA74] & 8 March 1931 \\
NE Bulgaria (11) & 2.5 & 5 & 7.0 [GRA78] & 14 June 1913 \\
Turkey (10) & 4.5 & 5 & 7.3 [SHA74] & 9 August 1912 \\
Unknown epicentre & 7.0 & 5 & - & 4 April 1904 \\
Generalized & 100 & 7 & External source: 7.2 & 1917 \\
\hline
\end{tabular}

(*) SHA74 = Shebalin et al. (1974); AMB01 = Ambraseys (2001); COR79 = Cornea and Radu (1979).

Table VI. Time changes of knowledge in the earthquakes felt in the southeastern Bulgarian territory.

\begin{tabular}{clccc}
\hline \hline \multicolumn{1}{c}{ Time period } & $\begin{array}{c}\text { All events affected } \\
\text { SE Bulgaria }\end{array}$ & $\begin{array}{c}\text { Events in Turkey only } \\
\text { Amount }\end{array}$ \\
\hline 5th cent. B.C.-19th cent. & $\begin{array}{l}\text { Before the Bulgarian Seismological } \\
\text { Survey establishment }\end{array}$ & 113 & 63 & 55.7 \\
5th cent. B.C.-11th cent. & & 34 & 29 & 85.3 \\
12th cent.-1891 & $\begin{array}{l}\text { After the Bulgarian Seismological Sur- } \\
\text { vey establishment (since 1892) } \\
\text { (incl. aftershocks of strong events } \\
\text { 19th cent.-21th cent. }\end{array}$ & 79 & 34 & 20.3 \\
\hline & SW Bulgaria \& Halkidiki) & 177 & 36 & \\
\hline
\end{tabular}

known effects, caused by distant earthquakes. Some details on damaging effects at Sofia in this period are given in table V.

Case $G$ - Seismic impact on SE Bulgaria.

Part of the significant seismic effects near the Bulgarian state borders comes from the neighbouring areas. Such effects are not to be neglect- ed, especially when the seismogenic zones are rapidly deformed and, consequently, show essential activity. For example, the SE territory of Bulgaria is under damaging influence from the Marmara Sea region more frequently than from local and nearly local origins. The long-term record of seismic effects on the south-eastern territory of 
(a)

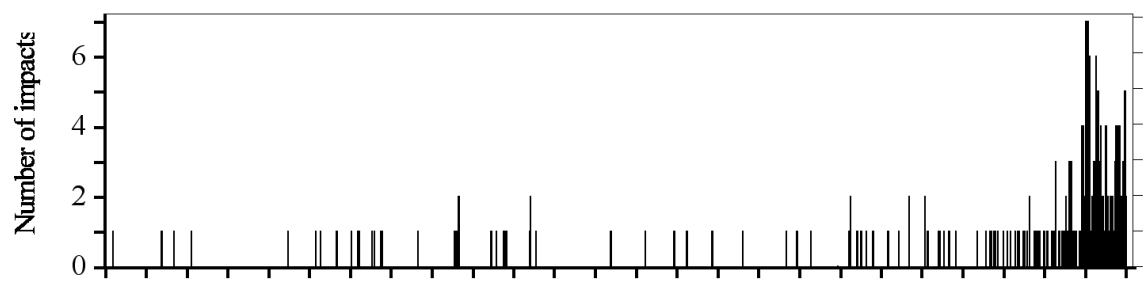

(b)

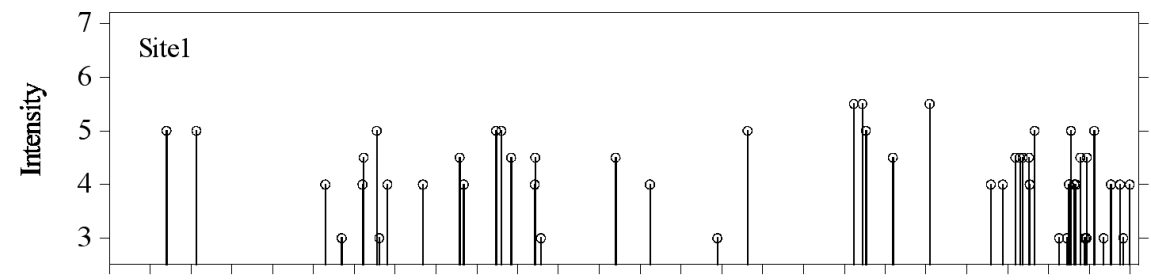

(C)

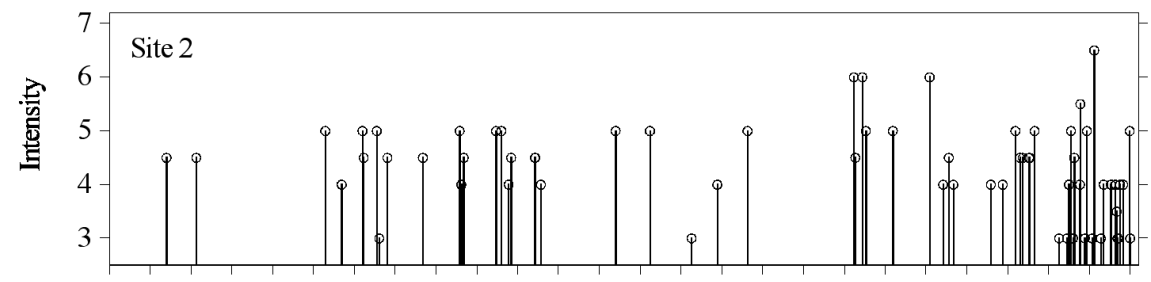

(d)

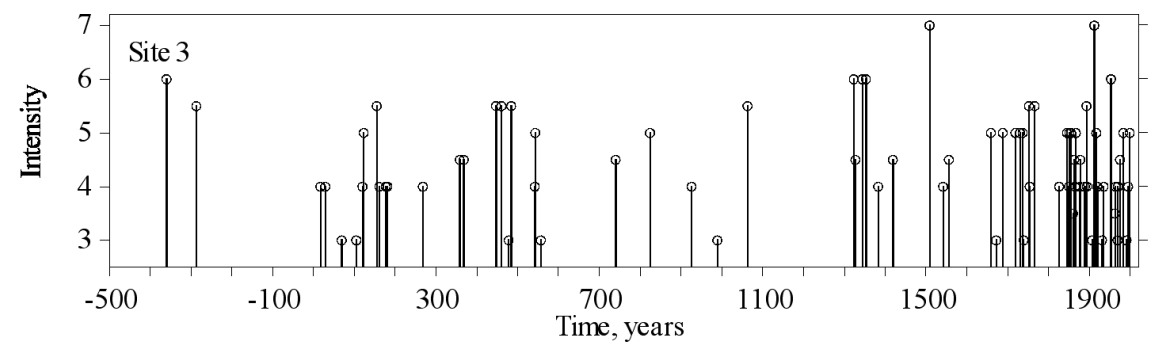

Fig. 5a-d. Time seismic history of the southeastern territory of Bulgaria, since the 5th B.C. (Case G): frequency of impacts from all earthquake sources (a); maximum strength (intensity) per year in Site 1 - the strongest impacts come from local origins (b), in Site 2 - the strongest impacts being from the western Marmara Sea region (c), and in Site 3 - either from the western Marmara Sea or Edirne area (d); Site 1 to Site 3 are marked in fig. 1.

Bulgaria has never been studied in detail. The forthcoming gas transmission via this territory and the importance of this area because of concentration of industrial and tourist sites in it encouraged this investigation.

For the time before the beginning of 20th century, catalogues of the other Balkan countries have been applied. For effects from Turkey, a catalogue sketched on the basis of coeval descriptions derived by Ambraseys and Finkel
(1991, 1995) and Guidoboni et al. (1994) was used. The strength of excitation in Bulgaria is calculated combining these catalogue parameters with the intensity attenuation based on well documented macroseismic patterns. Around 290 seismic effect observations on south-eastern Bulgaria have been identified for the time span since 5th century B.C. till now. The systematization in table VI clearly shows: a) poor information about the earthquake sequences in Bul- 
garia before the establishment of the National seismological survey, and b) a good knowledge on damaging historical earthquakes in Turkey, especially since the 18 th century.

The effects on three different sites (marked in fig. 1) are shown in fig. 5a-d. Intensity not exceeding $7 \mathrm{MSK}$ is noticed there. Consequently, there is no reason to preserve intensity $9 \mathrm{MSK}$ by the Bulgarian Code in the territory adjacent to Turkey. Bearing in mind the contemporary growth of the urban and industrial settlements and hence the increased density of population, the value of maximum 8 MSK might be the most realistic one.

\section{Comments and conclusions}

The development of non-instrumental seismology in Bulgaria has been reviewed. Tracing the history of previous earthquake catalogues and isoseismal maps, the main sources of initial descriptive information are discussed. It is concluded that these sources are qualitative enough but not uniform through the centuries. For instance, the new pieces of information on domestic events, recently disclosed, cover the time after the Bulgarian Renaissance started in the second half of the 18th century. They proceed from Greek, Bulgarian, Slavonic sources but not from Ottoman ones. Concerning the five-century Ottoman domination especially, the historian Gradeva (1999) concludes: «The Ottoman sources of local issuance or keeping are rather a poor source for the reconstruction of seismic activity in the Balkans through the centuries». How difficult it is to have successful searching for Bulgarian earthquakes in Ottoman sources, proceeds from the impressive efforts of Ambraseys and Finkel (1999): «... of some 500 earthquakes known from non-Ottoman sources for the Balkans during 1500-1800, only 41 were found in Ottoman sources but none in Bulgaria or Macedonia».

The time before the 18th century has been too slightly known by the seismology of Bulgaria.

Another important topic is how fully and how far critically the information sources have been exploited. In this connection, the macroseismic materials have been inspected; it is concluded that: 1) the final macroseismic products - bul- letins, catalogues, isoseismal and other intensity distribution maps - have not been prepared under clear requirements, and 2) some of the macroseismic materials have been used directly as supporting datasets. That is why the historical earthquake investigation since the last 20th century's decade has been directed to the supporting dataset improvement. The cases considered above are developed on reappraisal of first-hand primary information and for long-term dataset completing, the regional intensity attenuation features are seldom applied to the catalogue entries of strong past earthquakes (cases F, G). When interpreting and processing the initial records, they are managed in a specific way from case to case. The lessons we have learnt are:

- To avoid mixtures of first- and secondhand information sources, or of different intensity scales;

- To read the primary records many times and very carefully;

- To distinguish events of a series by the «relative time of occurrence»;

- To prefer records from distant sections of the felt area in cases after a strong earthquake occurrence;

- To check the authenticity of strong catalogue events, especially of those proceeding from a very poor dataset.

Generalizing, (1) the main factors, which might contribute to the improvement of the supporting dataset, turn out to have been: i) flexibility of the initial information management; ii) applying techniques recently involved in the historical seismology, or developing of new ones; iii) borrowing experience from the instrumental seismological monitoring, and (2) after supporting dataset improvement, the consecutive upgrading of knowledge can be achieved in two aspects: i) the key events and the overall seismicity of the region (cases C, D); ii) understanding of to what extent a certain territory is risky.

\section{Acknowledgements}

This work has been accomplished thanks to the helpful discussions within the framework of the ESC Working Group «Historical Seismolo- 
gy». The author is grateful to the referees for their reasonable suggestions.

\section{REFERENCES}

Ambraseys, N.N. (2001): The Kresna Earthquake of 1904 in Bulgaria, Ann. Geofis., 44 (1), 95-117.

AmbraseYs, N.N. and C. FinKEL (1995): The Seismicity of Turkey and Adjacent Areas (EREN, Istanbul), pp. 240.

AmbraseYs, N.N. and C. FinKEL (1999): Unpublished Ottoman archival information on the seismicity of the Balkans during the period 1500-1800, in Natural Disasters in the Ottoman Empire, edited by E. ZACHARIADOU, Institute for Mediterranean Studies, Halcyon Days in Crete III, a Symposium Held in Rethymnon (Greece), 10-12 January 1997, 89-107.

Ambraseys, N.N. and C. FinkEL (1991): Long-term seismicity of Istanbul and of the Marmara Sea region, Terra Nova, 3, 527-539.

Babachkova, B. and S.Rizhikova (1993): New data concerning the historic seismicity of Bulgaria, Bulg. Geophys. J., XIX (4), 83-100.

BEKKER, I (Editor) (1838): Symeon Magister: Chronographia, Berlin.

Christoskov, L. and E. SAmardjieva (1980): Possible sources for completing the historical part of an earthquake catalog - estimation and use, Bulg. Geophys. J., 6 (4), 44-53.

Comninakis, P. and B.C. Papazachos (1982): A Catalogue of Historical Earthquakes in Greece and Surrounding Area: 479 B.C.-1900 A.D. (Univ. of Thessaloniki, Geophys. Lab., Thessaloniki), pp. 24

CorneA, I. and C. RADU (Editors) (1979): Cercetari Seismologice Asupra Cutremurului Din 4 Martie 1977. Comitetul de stat pentru energia nucleara (Institutul central de fizica, Centrul de Fizica pamintului si seismologie, Bucuresti), 732-736, 737-751.

DE Boor, C. (Editor) (1883): Theophanes: Chronographia, Leipzig.

FuCHS, C.W.C. (1886): Statistik der Erdbeben von 18651885, Sitzungber. Kaiserl. Akad. Wiss., Math. Naturewiss. Kl. (Wien), 92 (1-5), 279-313.

Galanopoulos, A.G. (1960): A Catalogue of Shocks with $I_{0} \geq$ VI or $M \geq 5$ for the Years 1801-1958, Athens, pp. 119.

Galanopoulos, A.G. (1961): A Catalogue of Shocks with $I_{0} \geq$ VII for the Years prior to 1800 , Athens, pp. 18

GALT, J. (1812-1987): Voyages and Travels, in the Years 1809, 1810 and 1811; containing Statistical, Commercial, and Miscellaneous Observations on Gibraltar, Sardinia, Sicily, Malta, Serigo and Turkey (London), 308366, in English Travel Notes for the Balkans, edited by M. Todorova (Science and Art, Sofia), p. 520.

GlavcheVA, R. (1994): To what extent is acceptable the formalization of epicentre location on a few intensity data points. In: ESC XXIV Assembly, Athens, Sept. 19-24, 1994, p. 135 (abstract)

Glavcheva, R. (1996): On the Worth of Staiko Staikof's Collection in Historical Seismology, Bulg. Geophys. J., 22 (2), 27-35.

GlaVCHEVA, R. (1997): Macroseismic area size and magni- tude for the earthquakes in Bulgaria: empirical relations, Bulg. Geophys. J., 23 (1-2), 96-106.

Glavcheva, R. (2000a): How Plovdiv became involved in the 1759 Thessaloniki earthquake series and on the series itself, in Geodynamic Investigations on the Territory of Bulgaria - Investigations of the ChirpanPlovdiv Region Related to the 1928 Earthquake (monograph), Warsaw Univ. of Technology, Inst. of Geodesy and Geodetic Astronomy, Reports on Geodesy, 3 (48), 43-50.

GlavCHEVA, R. (2000b): On the seismic energy release in the transfrontier region of SW Bulgaria - Macedonia at the beginning of the 20th century, in Geodynamic Investigations on the Territory of Bulgaria - Investigations of the Krupnik-Kresna Region Related to the 1904 Earthquake (monograph), Warsaw Univ. of Technology, Inst. of Geodesy and Geodetic Astronomy, Reports on Geodesy, 4 (49), 13-21.

GlavCHEVA, R. and C. RADU (1994): The earthquake of October 14th, 1892 in Central Balkans: a transfrontier case, in Historical Investigation of European Earthquakes, Materials of the CEC project «Review of Historical Seismicity in Europe», edited by P. AlBINI and A. Moroni (CNR, Milano), vol. 2, 215-223.

Glavcheva, R., I. Tzoncheva and Sv. Maslinkova (2000): Seismicity spatiotemporal organization before the 1928 catastrophic earthquakes in Bulgaria, in Geodynamic Investigations on the Territory of Bulgaria - Investigations of the Chirpan-Plovdiv Region Related to the 1928 Earthquake (monograph), Warsaw Univ. of Technology, Inst. of Geodesy and Geodetic Astronomy, Reports on Geodesy, 3 (48), 29-38.

GRADEVA, R. (1999): Ottoman and Bulgarian sources on earthquakes in Central Balkan lands, in Natural Disasters in the Ottoman Empire, edited by E. ZACHARIADOU, Institute for Mediterranean Studies, Halcyon Days in Crete III, a Symposium Held in Rethymnon (Greece), 10-12 January 1997, 55-65.

Grigorova, E. (1973): Catalogue of the earthquakes in Bulgaria before 1900, Sofia, Manuscript to Balkan Earthquake Catalogue.

Grigorova, E. and B. Grigorov (1964): Epicentres and Seismic Lines in P.R. of Bulgaria (Publishing House of Bulg. Acad. Sci., Sofia).

Grigorova, E., Christoskov, L., Sokerova, D., RizhikoVA, S., Roglinov, A. (1978): Catalogue of earthquakes in Bulgaria and the nearby territories during the period 1st cent. B.C.-1977, Archives Geophys. Inst., Bulg. Acad. Sci., Sofia.

Grigorova, E., and S. RizhiKova (1966): Tremblements de Terre en Bulgarie au Cours de 1961 a 1964 (Editions de l'Acad. Bulg. Sci., 105, Sofia).

GuÉNEAU DE MONTBÉliard (Editor) (1761): Liste chronologique des éruptions de volcans, de tremblements de terre,... jusqùen 1760, Collection Académique, Partie Etrangère, t.VI, pp. 488-681.

Guidoboni, E., A. Comastri and G. Traina (Editors) (1994): Catalogue of Ancient earthquakes in the Mediterranean Area up to the 10th century (ING, Roma, SGA, Bologna), pp. 504.

HofF, K.E.A. VON (1840): Chronik der Erdbeben und VulcanAusbrüche, I. Theil (Justus Perthes, Gotha), pp. 470.

ILEFF, N. (1952): Les tremblements de terre en Bulgarie 
ressentis pendent les annees 1946-1950, in: Annual issue of Directorate of geological and mine investigations (Sofia) 5, 442-491 (in Bulgarian, resume in French).

KARNIK, V. (1971): Seismicity of the European area, Part II (D. Reidel Publ. Comp., Dordrecht, Holland), pp. 218.

Kirov, K. (1931): Tremblements de Terre en Bulgarie Ressentis Pendant les Annees 1917-1927, Sofia (in Bulgarian, abstract and tables in French).

Kirov, K., E. Grigorova and N. IleFF (1960): Contribution to the seismicity of Bulgaria. Izv. Geophys. Inst., Bulg. Acad. Sci., 1, 137-183 (in Bulgarian).

MALLET, R. (1853): Catalogue of recorded earthquakes from 1606 B.C. to A.D. 1850, Brit. Ass. Rep., 1853, 1-176.

Minailovic, J. (1932): Data on South Bulgarian Seismicity 1749-1931, Spomenik Srb. Kr. Akad., LXXVIII (17), pp. 153.

MiLnE, J. (1911): A Catalogue of Destructive Earthquakes A.D. 7 to A.D. 1899, BAAS (London), pp. 92.

MontANDON, F. (1953): Les tremblements de terre destructeurs en Europe (Genève), pp. 195.

MushKETOV, I.V. and A.P. ORLOV (1893): Catalogue of earthquakes in Russian Empire, 26, p. 582 (in Russian).

Perrey, A. (1850): Memoire sur les tremblements de terre ressentis dans la peninsule Turco-hellenique et en Syrie, in Memoires Couronnes et Memoires des $\mathrm{Sa}$ vants Etrangers, Acad. R. Sci. de Belgique, Bruxelles, 23 (1), p. 50.

ProchaZKova, D. and V. KARNIK (Editors) (1978): Atlas of Isoseismal Maps for Central and Eastern Europe
(Geophys. Inst. Czechosl. Acad. Sci., Prague).

SchMiDT, J. (1879): Studien ueber Vulkane und Erdbeben, II, Leipzig.

Shebalin, N.V. (Editor) (1974): Atlas of isoseismal maps, UNDP-UNESCO Survey of the Seismicity of the Balkan Region, Part III, Skopje, 275 maps.

SHEBALIN, N.V., V. KÁRNíK and D. HADZIEVSKI (Editors) (1974): Catalogue of earthquakes of the Balkan region, UNDP-UNESCO Survey of the Seismicity of the Balkan Region, Part I and Part II, Skopje, pp. 600.

Sieberg, A. (1932): Die Erdbeben, in Handbuch der Geophysik, edited by B. GUTENBERG (Berlin), vol. IV.

SoKerova, D., S. RizhiKova and R. Glavcheva (1982): Catalogue of earthquakes in Bulgaria during the period 1970-1980, in National Report of Bulgaria, UNDP/UNESCO and UNDRO Project RER/79/014 Earthquake Risk Reduction in the Balkan Region, Working Group A: Seismology, Seismotectonics, Seismic Hazard and Earthquake Prediction, Final Report, Athens, December 1982, A47-A49.

StAikoff St. (1930): Materiel sur la seismographie de la Bulgarie, la Thrace et la Macedoine, J. Bulg. Acad. Sci., XLII, Sofia, pp. 15-45.

Watzof, S. (1902, 1903,..., 1923): The earthquakes in Bulgaria. Report on the earthquakes felt in XIXc., and during 1901, 1902,..., 1913-1916, Centr. Meteorol. Inst., (Sofia), 1-17 (in Bulgarian, in French).

Watzof, S. (1908, 1912): Materials about the seismography of Bulgaria. Information on previous centuries earthquakes, Spisan, BAN, 127-134, 225-228. 